\title{
Література:
}

1. Агаркова А. О. Формування професійно-етичної культури майбутніх лікарів у вищих навчальних закладах : автореф. дис ... канд. пед. наук: 13.00.07 / А. О. Агаркова. - Київ, 2011. - 22 с.

2. Кульбашна Я. А. Формування професійної компетентності майбутніх фахівців із стоматології: теоретичні й методичні основи : монографія / Я. А. Кульбашна ; Інститут вищої освіти Національної академії педагогічних наук України, Національний медичний університет імені О. О. Богомольця. - Київ : Компас, 2014. - 415 с.

3. Подласый И. П. Педагогика: 100 вопросов - 100 ответов: учебное пособие для вузов / И. П. Подласый. - М.: ВЛАДОС-пресс, 2004. -365 c.

DOI https://doi.org/10.30525/978-9934-26-114-5-55

\section{ВИКОРИСТАННЯ ДИСТАНЦЙНИХ ПЛАТФОРМ ТА ОНЛАЙН-СЕРВІСІВ В УМОВАХ ВІДДАЛЕНОГО НАВЧАННЯ ІНОЗЕМНОЇ МОВИ В НЕМОВНИХ ЗВО}

\author{
Мірошниченко Г. В.
}

старший викладач кафедри іноземних мов

Національний аерокосмічний університет імені М. С. Жуковського «Харківський авіаційний інститут»

Опаріна C. B.

старший викладач кафедри іноземних мов

Національний аерокосмічний університет імені М. С. Жуковського

«Харківський авіаційний інститут» м. Харків, Україна

На сьогоднішній день у зв'язку 3 ситуацією в світі система дистанційного навчання набула особливої актуальності. Загальна доступність Інтернету i простота його використання сприяли досить швидкому переходу ЗВО на дистанційне навчання в умовах оголошеного по всьому світу карантину. Дистанційне навчання також розглядають і як форму, і як одну зі складових всієї системи освіти, за якої взаємодія викладача і студентів здійснюється на відстані i відображає всі властиві навчальному процесу компоненти (цілі, зміст, методи, організаційні форми, засоби навчання), реалізовані специфічними засобами Інтернет-технологій [1]. 
Специфіка дисципліни «Іноземна мова» для студентів немовних спеціальностей пов'язана перш за все з тим, що навчання спрямовано не на засвоєння основ наук, а на оволодінням новою мовою, способами використання цієї мови - аудіюванням, говорінням, читанням і письмом. Іншою специфічною рисою іноземної мови $є$ іiї предметність, професійна спрямованість, що означає необхідність навчання іноземної мови для подальшого спілкування в професійній сфері. При цьому мета навчання іноземної мови полягає у формуванні у студентів немовних спеціальностей комунікативної компетенції. Система дистанційної освіти сприяє ефективності засвоєння іноземної мови студентами немовних спеціальностей, адже вона дозволяе збільшити обсяг мовної практики, використовуючи можливості інтернет-сервісів.

Таким чином, необхідно відзначити, що дистанційне навчання сприяє реалізації сучасної освітньої парадигми, невід'ємними компонентами якої $є$ особистісно-орієнтоване навчання, індивідуалізація i диференціація навчальної діяльності, можливість автономного навчання, самоосвіта і саморозвиток учнів.

Платформу дистанційного навчання, у найбільш загальному вигляді, можна визначити як програмне забезпечення, яке уможливлює реалізацію педагогічних та інформаційних технологій дистанційного навчання шляхом автоматизації створення і отримання знань у системі дистанційного навчання, а також завдяки наявності засобів, необхідних для трьох основних користувачів - викладача, студента та адміністратора Онлайн-сервіси (online services) являють собою Інтернет-ресурси, що надають різноманітну інформацію та послуги користувачам, включаючи й можливості їх онлайн-спілкування. Платформи дистанційного навчання та онлайн-сервіси бувають комерційні та безкоштовні.

Зважаючи на обмежений обсяг доповіді та все зростаючу кількість платформ дистанційного навчання на базі рішень Open Source, охопити всі 3 них видається неможливим, тому будуть розглянути найперспективніші та найзручніші рішення 3 існуючих на сьогоднішній момент, до яких ми відносимо Moodle та Google Classroom.

Платформу дистанційного навчання Moodle (Modular ObjectOriented Dynamic Learning Environment) просто неможливо не згадати, адже ця система є однією з найпопулярніших у світі, використовується у більш ніж 100 країнах. На додачу до цього іiі можна вільно завантажити з мережі Інтернет. Платформа дозволяє створювати якісні дистанційні курси, іiі можливості аж ніяк не гірші за функціонал багатьох комерційних систем, до того ж іï можна підлаштовувати під потреби певного навчального проекту та доповнювати новими 216 
сервісами. На базі даної системи було створено внутрішньо університетську систему Ментор, яка використовується викладачами нашої кафедри.

Наступна платформа Classroom - розробка компанії Google, яка покликана полегшити роботу викладачів та зробити ії ефективною. Він інтегрований з Google Docs, Drive, Gmail та є складовою спеціалізованого освітнього пакета Google Apps for Education разом з календарем, електронною поштою та іншими програмами.За допомогою інтерактивного сервісу Classroom викладач зможе організувати комунікації зі студентами, швидко готувати завдання та проводити заняття. Під час розробки завдання викладач може: скористатися опцією спільного доступу до документа, або ж опцією автоматичного створення копії для кожного студента, побачити, хто закінчив виконання завдання, а хто - ні, забезпечити зворотний зв'язок та поставити запитання студентами в режимі реального часу як в класі, так і поза його межами. Не можна не відзначити, що Google Classroom має декілька важливих переваг серед інших подібних рішень, а саме: по-перше, це перевірені часом сервіси, які об'єднано в межах однієї програми, по-друге, велика користувацька аудиторія.

3 точки зору навчання іноземної мови проаналізовані платформи надають достатньо можливостей для ефективної організації процесу дистанційного навчання. Зокрема навички письма іноземною мовою добре розвиваються при використанні студентами чатів та форумів, де вони можуть спілкуватися як один 3 одним, так і персонально 3 викладачем. 3'являється велика кількість можливостей для розвитку навичок аудіювання, оскільки студенти більше не прив'язані до очних занять та обмеженої кількості прослуховувань обмеженої кількості матеріалу. Перевірити якість виконання студентами такої самостійної роботи дуже легко, адже по проходженні певного матеріалу студентам можна запропонувати виконати тестові завдання 3 аудіювання під час яких після прослуховування аудіоматеріалів задану викладачем кількість разів вони повинні будуть відповісти за тестові питання. До речі, час на надання відповідей можна обмежувати, а результат, отриманий студентом, буде автоматично перевірений без залучення викладача 3 можливістю миттєвого ознайомлення студента з результатом тестування.

Розглянувши платформи, що мають значний потенціал для організації дистанційного навчання іноземної мови, звернемося до онлайн-сервісів, які можуть успішно застосовуватися з цією ж метою та ефективно доповнити систему дистанційної освіти. Зважаючи на обмежений обсяг нашої роботи, ми, спираючись на усне опитування 
студентів, обрали лише три найперспективніші онлайн-сервіси, а саме: Busuu, Lingua Leo. Розпочнемо 3 Busuu, який $€$ цілою онлайнспільнотою з вивчення іноземних мов. Три основні принципи, на яких базується система: вчитися у носіїв мови, вчитися на автентичному матеріалі, вчитися безкоштовно. Кожен член спільноти виступає в ролі не тільки учня, але й вчителя, який допомагає бажаючим засвоїти власну рідну мову. Онлайн-уроки виконані у простій та цікавій формі зі зрозуміло озвученими фразами, картинками, інтерактивними вправами та можливістю взаємодіяти 3 іншими користувачами. Система має певні недоліки, зокрема незначну кількість граматичних вправ, через що не вийде добре вивчити граматику, до того ж кількість лексики $\epsilon$ також обмеженою, а тому навряд чи вдасться здобути широкий словниковий запас. Проте $\epsilon$ і переваги, які викладач може використати, порадивши студентам застосувати цей ресурс під час самостійної роботи, до них належать: добре розроблені вправи, спрямовані на заучування розмовних фраз та можливість спілкування з носіями мови, якої так часто бракує нашим студентам. Учасників-носіїв мови можна додавати у друзі, спілкуватися на різні теми та просити перевірити завдання. Усе це сприятиме розвиткові навичок письма та читання [2].

Наступний онлайн-сервіс, який ми розглянемо, може допомогти студентам добре розширити словниковий запас, а також удосконалити навички читання та аудіювання, адже LinguaLeo пропонує вивчати мову на матеріалах, що дуже цікаві для користувачів, зокрема: аудіокнигах, піснях, відеозаписах та текстах, які були розміщені на відкритих ресурсах або завантажені іншими учасниками.

Отже, аналіз навіть такої невеликої кількості онлайн-сервісів дає змогу зрозуміти, що універсальний ресурс із самостійного вивчення мови, який би допомагав однаково добре розвинути навички та вміння аудіювання, говоріння, читання та письма, навряд чи існує. Кожен окремий сервіс концентрується на розвиткові тих чи інших навичок й умінь, і лише вдале поєднання ресурсів може забезпечити всебічну підготовку та ефективну організацію самостійної роботи студентів. Звичайно ж, провідне місце в системі дистанційного навчання відіграє викладач, від якого залежить виважений вибір платформи дистанційного навчання, що стане основою для побудови відповідної методики навчання іноземної мови. Саме викладач може надати студентам поради з успішної організації їхньої самостійної роботи із використанням сучасних онлайн-ресурсів.

Перехід на систему дистанційного навчання ставить перед викладачами ЗВО завдання освоєння і впровадження сучасних освітніх та технічних засобів, а також розробки дистанційних курсів, кожен з яких 218 
представляє собою особливим чином сконструйовано систему навчання в інтернет-середовищі. Відбір і організація змісту навчання іноземної мови студентів немовних спеціальностей в дистанційному режимі залежать від мети, вибору моделі дистанційного навчання, можливостей програмного забезпечення, компетентності педагогічних кадрів та готовності учасників освітнього процесу до взаємодії у мережі.

\title{
Література:
}

1. Бутиріна М. В. Теоретичні основи дистанційного навчання у галузі технологічної освіти України [Електронний ресурс] / М. В. Бутиріна, О. О. Бондаренко, М. Г. Погорєлов // Режим доступу: http://www.nbuv.gov.ua/old_jrn/Soc_Gum/Vchdpu/ped/2012_97/Butyr.pdf.

2. Петренко Л. М. Сучасні тенденції модифікацій педагогічних технологій в освіті дорослих / Лариса Михайлівна Петренко // Витоки педагогічної майстерності: зб. наук. праць / Полтав. нац. пед. ун-т імені В. Г. Короленка. - Полтава, 2013. Вип. 11. - С. 256-261. (Серія «Педагогічні науки»).

DOI https://doi.org/10.30525/978-9934-26-114-5-56

\section{РОЗГЛЯД МАЙБУТНІМИ РЕДАКТОРАМИ НОРМАТИВНИХ АСПЕКТІВ ПЕРЕКЛАДУ В ПРОЦЕСІ ГЕРМЕНЕВТИЧНОГО АНАЛІЗУ ТЕКСТІВ}

\author{
Мішеніна Т. М. \\ професор кафедри украӥнської мови \\ Криворізький державний педагогічний університет \\ Качайло К. А. \\ доиент кафедри украӥнської мови \\ Криворізький державний педагогічний університет \\ м. Кривий Ріг, Дніпропетровска область, Украӥна
}

Фахова підготовка майбутніх редакторів орієнтована на вивчення низки дисциплін, які забезпечують не лише засвоєння знань, які стосуються понятійно-категорійного апарату редакційно-видавничої й колекційної діяльностей, але й знання, які становлять основу теорії i практики перекладу. Оскільки редагування освітніх видань передбачає діагностування мовних девіацій, подальше їх усунення на основі алгоритму редагування типу помилок (фонетико-орфоепічних, 